\title{
Studies on the nitrogen compounds of the faeces of dairy cows fed urea as the sole or partial source of nitrogen
}

\author{
Terttu Ettala and Matti Kreula \\ Biochemical Research Institute, Kalevankatu 56 b, SF-00180 Helsinki 18, Finland
}

\begin{abstract}
The nitrogen compounds of the faeces of dairy cows on purified, proteinfree feed with urea and small amounts of ammcnium salts as the sole source of nitrogen ( 0 -feed), on low-protein feed in which part of the protein was replaced with urea (ULPfeed) and on normal protein-containing feed (NorP-feed) were studied.

The total nitrogen contents of the dry matter of the faeces were $2.5 \pm 0.7 \%$ on 0 -feed, $2.4 \pm 0.4 \%$ on ULP-feed and $2.3 \pm 0.6 \%$ on NorP-feed. The proportion of urea- and ammonium nitrogen of the total nitrogen was $3.2 \pm 2.4,4.5 \pm 2.4$ and $3.7 \pm$ $1.8 \%$ respectively, and the proportion of nitrogen soluble in $70 \%$ ethanol $10.9 \pm 5.7$, $9.9 \pm 2.4$ and $10.4 \pm 3.8 \%$ of the total nitrogen; the proportion of nitrogen in the free amino acid fraction was $4.1 \pm 2.9$ on 0 -feed, $1.6 \pm 1.4(\mathrm{P}<0.05)$ on ULP-feed and $3.2 \pm 2.9 \%$ on NorP-feed.

The nitrogen insoluble in $70 \%$ ethanol as a proportion of the total nitrogen was $82.3 \pm 7.2$ on 0 -feed, $85.4 \pm 5.0$ on ULP-feed and $82.3 \pm 7.2 \%$ on NorP-feed.

Of the total nitrogen of this insoluble fraction, the following proportions were released as amino acids by acid hydrolysis: $62.3 \pm 8.5 \%$ on 0 -feed, $61.6 \pm 10.7 \%$ on ULP-feed and $59.0 \pm 13.9 \%$ on NorP-feed. $\boldsymbol{c}, \varepsilon$-diaminopimelic acid was $1.7 \pm 0.6$, $0.7 \pm 0.2(\mathrm{P}<0.05)$ and $1.2 \pm 0.4 \mathrm{~mol} \%$ respectively of the total amino acids of the hydrolyzate.

The soluble nitrogen fraction was separated into free amino acid and speptiden fractions, and the amino acid composition of both was determined, the latter after acid hydrolysis.
\end{abstract}

\section{Introduction}

The faeces and urine of ruminants contain a considerable amount of nitrogen, for example residue from metabolism, indigestible feed nitrogen and large amounts of microbial nitrogen synthesized in the rumen and to some extent also in the large intestine, which has passed undigested and unabsorbed through the alimentary canal.

It is difficult to determine what proportion of the nitrogen of the faeces of cows on normal feed is indigestible feed nitrogen and what is microbial nitrogen. With cows fed purified protein-free feed with urea (and a small amount of ammonium salts) as the sole source of nitrogen, all the protein available is produced by bacteria (VIRTANEN 1956). The digestibility of nitrogen 
averaged $67 \%$ in these feeding experiments, so that $33 \%$ of the urea nitrogen fed was removed in the faeces. In the present study the composition of the nitrogenous fraction of the faeces was studied. Further, we studied the faeces of cows on a feed containing small amounts of protein, the protein deficiency being made good with urea. With these cows also the amount of nitrogen removed in the faeces was almost $30 \%$ of the amount fed (KrEULA and EtTala 1977).

\section{Materials and methods}

All the cows included in the test were Ayrshire dairy cows. Those fed protein-free feed with urea as the sole source of nitrogen are called 0 -cows and the feed 0 -feed. Those fed small amounts of protein and plenty of urea are called ULP-cows and the feed ULP-feed. Both of these feeds have been described in previous publications (VIRTANen 1963, 1966, 1967, EtTala and KREULA 1976). Samples of faeces were collected at different stages of lactation from both feeding groups during a period of several years. For comparison samples were also taken from cows on ordinary indoor and pasture feeds (NorP-feed, NorP-cows).

The dry matter was determined by drying the samples at $100^{\circ} \mathrm{C}$ or in vacuo at $60^{\circ} \mathrm{C}$. Nitrogen was determined according to the Kjeldahl method using $\mathrm{KMnO}_{4}$ (BEET 1955). Total nitrogen was determined on fresh faeces. Soluble nitrogen was extracted with $70 \%$ ethanol from fresh faeces. The free amino acid fraction was isolated from the soluble nitrogen fraction with Amberlite IR 120 cation ion exchanger (in $\mathrm{H}^{+}$form). The so-called peptide fraction (eluted with water from Amberlite IR 120) was hydrolyzed (6 M HCl, $20 \mathrm{~h}$, $106^{\circ} \mathrm{C}$, under $\mathrm{N}_{2}$ ) and the amino acids of the hydrolyzate were purified on Amberlite IR 120.

The fraction insoluble in $70 \%$ ethanol was hydrolyzed $(6 \mathrm{M} \mathrm{HCl}, 20 \mathrm{~h}$, $106^{\circ} \mathrm{C}$, under $\mathrm{N}_{2}$ ) and the amino acids were purified as above using Amberlite IR 120. Nitrogen was determined on all the fractions by the Kjeldahl method. The quantitative amino acid determinations were made with an amino acid analyzer, constructed in our laboratory (PIEz and MoRRIs 1960) or with a Bio Cal BC 100 amino acid analyzer.

Under these hydrolysis conditions tryptophan is decomposed completely and methionine, cystine and glucosamine partly. Further, the high carbohydrate content in the faeces fractions resulted in the formation of humin during hydrolysis, thus making quantitative recovery more difficult. Part of the tyrosine of the hydrolyzate was evidently retained in the humin, so that the contents of tyrosine obtained are too low. Without acid hydrolysis it was impossible to bring the entire insoluble nitrogen fraction of the faeces into solution. Using an ultrasonic disintegrator (MSE Ultrasonic Disintegrator, $150 \mathrm{~W}$ ) a maximum of $80 \%$ of the total nitrogen could be solubilized. Neither was it possible to recover the amino acids completely by enzyme hydrolysis. Amino acid analyses were made during a period of several years with two different amino acid analyzers. During this time the methods were developed, one of the results being that the number of identified amino acids increased. 


\section{Results}

The total nitrogen contents of the faeces and the distribution of nitrogen in the different fractions were determined in samples from 0-, ULP- and NorPcows. The average results according to feeding group are given in Table 1 . For 0 -cows the total nitrogen content was $2.5 \pm 0.7$, ULP-cows $2.4 \pm 0.4$ and NorP-cows $2.3 \pm 0.6 \%$ of the dry matter. In each group there were large between sample differences, but the differences between the average values of the groups were not statistically significant, with the exception of the free amino acid nitrogen with ULP-cows, which, as a proportion of the total faecal nitrogen, showed an almost significant $(P<0.05)$ difference from the corresponding values of 0 - and NorP-cows.

In all of the groups most of the nitrogen of the faeces was insoluble in $70 \%$ ethanol. The nitrogen of the amino acids released from this fraction by acid hydrolysis was about $60 \%$ of the total nit:ogen of the faeces. The amino acids of the hydrolyzate from the faeces of $0-$, ULP- and NorP-cows are given in Table 2 as a mol \% of the total identified amino acids. In all feeding groups $a, \varepsilon$-diaminopimelic acid and glucosamine were present in this fraction; with 0 -cows their content as a proportion of the total amount of amino acids was greater than with the other feeding groups. The proportion of glycine, histidine and arginine of the total amino acids was smaller with 0 - and ULP-cows than with NorP-cows, and the differences were statistically significant $(\mathrm{P}<0.05)$. In contrast, the proportion of glutamic acid, methionine, isoleucine and tyrosine of the total amino acids with 0 - and ULP-cows was much greater than with NorP-cows, and the differences were significant.

The proportion of nitrogen soluble in $70 \%$ ethanol in all the feeding groups was about $10 \%$ of the total nitrogen. The free amino acids of this fraction from 0 - and ULP-cows were determined (Fig. 1).

Their total amount was on average 10.5 and $0.9 \mathrm{mg} / \mathrm{g}$ dry faeces with 0 and ULP-cows respectively. In both feeding groups the amount of alanine was the highest, the proportion of which in the total identified free amino acids averaged 25.7 with 0 -cows and $19.7 \mathrm{~mol} \%$ with ULP-cows. The total amount of amino acids liberated by hydrolysis of the peptide fraction was 1.4

Table 1. Nitrogen fractions of the faeces of cows on $0-$, ULP- and NorP-feeds.

\begin{tabular}{|c|c|c|c|}
\hline & $\begin{array}{l}0 \text {-covrs } \\
\mathrm{n}=32\end{array}$ & $\begin{array}{l}\text { ULP-cows } \\
\mathrm{n}=19\end{array}$ & $\begin{array}{c}\text { NorP-cows } \\
\mathrm{n}=9\end{array}$ \\
\hline Dry matter $\%$ & $18.1 \pm 3.3$ & $19.0 \pm 2.9$ & $15.6 \pm 1.6$ \\
\hline Total N, $\%$ of dry matter & $2.5 \pm 0.7$ & $2.4 \pm 0.4$ & $2.3 \pm 0.6$ \\
\hline $\mathrm{N}$ soluble in $70 \%$ ethanol, $\%$ of tot. $\mathrm{N}$ & $10.9 \pm 5.7$ & $9.9 \pm 2.4$ & $10.4 \pm 3.8$ \\
\hline Urea and $\mathrm{NH}_{4} \mathrm{~N}, \%$ of tot. $\mathrm{N}$ & $3.2 \pm 2.4$ & $4.5 \pm 2.4$ & $3.7 \pm 1.8$ \\
\hline Free amino acid $\mathrm{N}, \%$ of tot. $\mathrm{N}$ & $4.1 \pm 2.9$ & $\left.1.6 \pm 1.4^{*}\right)$ & $3.2 \pm 2.9$ \\
\hline Peptide fraction N, \% of tot. $\mathrm{N}$ & $2.8 \pm 2.1$ & $3.4 \pm 2.9$ & $4.5 \pm 1.7$ \\
\hline $\mathrm{N}$ insoluble in $70 \%$ ethanol, $\%$ of tot. $\mathrm{N}$ & $82.3 \pm 7.2$ & $85.4 \pm 5.0$ & $82.3 \pm 7.2$ \\
\hline Protein $\mathrm{N}, \%$ of tot. $\mathrm{N}$ & $62.8 \pm 8.5$ & $61.6 \pm 10.7$ & $59.0 \pm 13.9$ \\
\hline
\end{tabular}

*) $\mathrm{P}<0.05$ 
Table 2. Amino acid composition of the insoluble fraction hydrolyzate of the faeces (mol \% of total amino acids).

\begin{tabular}{lccc}
\hline $\begin{array}{c}\text { Amino } \\
\text { acid }\end{array}$ & $\begin{array}{c}0 \text {-cows } \\
\mathrm{n}=14\end{array}$ & $\begin{array}{c}\text { ULP-cows } \\
\mathrm{n}=9\end{array}$ & $\begin{array}{c}\text { NorP-cows } \\
\mathrm{n}=5\end{array}$ \\
\hline & & & \\
Asp & $9.1 \pm 1.4$ & $10.6 \pm 0.7^{*}$ & $8.1 \pm 0.3$ \\
Thr & $5.9 \pm 0.3$ & $6.2 \pm 0.3^{*} \mathrm{~N}$ & $5.5 \pm 0.6$ \\
Ser & $5.9 \pm 0.4^{*} \mathrm{~N}$ & $6.2 \pm 0.4$ & $6.4 \pm 0.3$ \\
Glu & $12.0 \pm 1.5$ & $11.9 \pm 0.8$ & $9.0 \pm 0.5^{*}$ \\
Pro & $4.1 \pm 0.4^{*}$ & $4.9 \pm 0.6$ & $5.4 \pm 0.7$ \\
Gly & $8.8 \pm 1.1$ & $10.1 \pm 1.8$ & $15.4 \pm 1.9^{*}$ \\
Ala & $13.8 \pm 1.2$ & $12.3 \pm 1.7^{*}$ & $13.9 \pm 1.0$ \\
Cys & $0.4 \pm 0.3$ & $0.6 \pm 0.2$ & $0.4 \pm 0.1$ \\
Val & $6.4 \pm 0.7$ & $6.6 \pm 0.8$ & $5.5 \pm 0.7^{*}$ \\
Met & $1.4 \pm 0.4$ & $1.0 \pm 0.3$ & $0.4 \pm 0.2^{*}$ \\
$\mathrm{~A}_{2}$ pm & $1.7 \pm 0.6$ & $0.7 \pm 0.2 * \mathrm{O}$ & $1.2 \pm 0.4$ \\
Ile & $5.0 \pm 0.7$ & $4.8 \pm 0.4$ & $3.6 \pm 0.1^{*}$ \\
Leu & $7.3 \pm 0.9$ & $7.0 \pm 0.4$ & $6.2 \pm 0.3^{*}$ \\
Tyr & $2.0 \pm 0.5$ & $2.2 \pm 0.4$ & $1.1 \pm 0.2^{*}$ \\
$\beta$ Ala & $2.5 \pm 2.1$ & $2.4 \pm 1.6$ & 0 \\
Phe & $3.9 \pm 0.9$ & $4.0 \pm 1.1$ & $2.4 \pm 0.1^{*}$ \\
Abu & $0.6 \pm 0.6$ & $0.6 \pm 0.5$ & $0.6 \pm 0.2$ \\
Orn & $0.5 \pm 0.5$ & $0.3 \pm 0.1$ & $0.5 \pm 0.5$ \\
Lys & $5.8 \pm 1.1$ & $5.6 \pm 1.2$ & $6.8 \pm 1.4$ \\
His & $0.9 \pm 0.2$ & $1.0 \pm 0.3$ & $1.9 \pm 0.5^{*}$ \\
Arg & $2.3 \pm 0.6$ & $2.2 \pm 0.9$ & $5.3 \pm 1.1^{*}$ \\
GlcN & $2.9 \pm 1.9$ & $2.2 \pm 0.3$ & $1.3 \pm 0.2$ \\
\hline
\end{tabular}

* significantly different from the other two values $(\mathrm{P}<0.05)$ as indicated by analysis of variance and Tukey's t-test

*O significantly different from 0 -cow value $(\mathrm{P}<0.05)$

${ }^{*} \mathrm{~N}$ significantly different from NorP-cow value $(\mathrm{P}<0.05)$

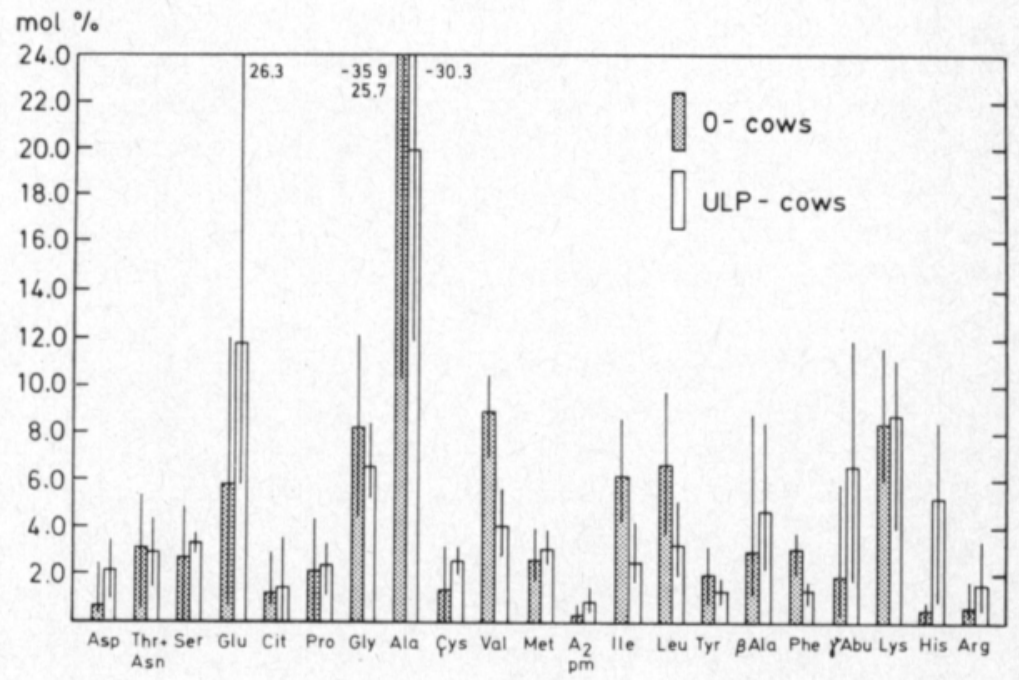

Figure 1. Free amino acids of the faeces, as mol $\%$ of the amount of all the free amino acids with 0 - and ULP-cows. 
and $1.6 \mathrm{mg}$ per $\mathrm{g}$ dry faeces with 0 - and ULP-cows respectively (Fig. 2). Of these amino acids the proportion of glutamic acid with 0 -cows was on the average $19.1 \pm 5.6$, that of glucosamine $9.1 \pm 6.1$ and $\beta$-alanine $13.3 \pm 4.1$; the corresponding figures with ULP-cows were $12.9,11.1$ and $16.1 \mathrm{~mol} \%$.

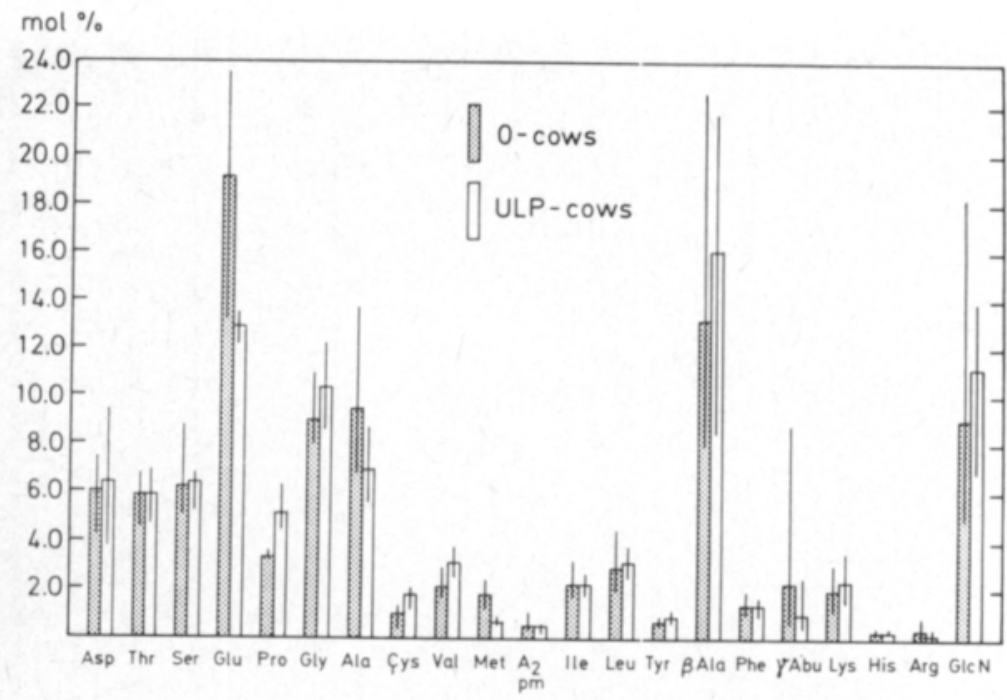

Figure 2. Amino acids of the speptides fraction hydrolyzate of the faeces as mol \% of the total amount of the amino acids with 0 - and ULP-cows.

Besides the amino acids in Fig. 1 and 2, unidentified ninhydrin-positive compounds were present in the free amino acid fractions and "peptiden fractions.

\section{Discussion}

The average composition and relative proportion of the nitrogen fractions of the feaces of the cows in the different feeding groups differed surprisingly little, even though the 0-cows' sole source of feed nitrogen was urea, the ULPcows received both urea and feed protein, and the NorP-cows consumed feed protein and no urea at all.

With all the feeding groups most of the nitrogen of the faeces was insoluble in $70 \%$ ethanol, the proportion of the total nitrogen being $82.3 \pm 7.2$ with 0 -cows, $85.4 \pm 5.0$ with ULP-cows and $82.3=7.2 \%$ with NorP-cows. MÄKINEN (1972) found that the proportion of insoluble nitrogen in the rumen was greater with 0 - and ULP-cows than with NorP-cows. The amino acid composition of the hydrolyzate of the insoluble fraction differed to some extent in the various groups.

The amount of $\alpha, \varepsilon$-diaminopimelic acid in the faeces of 0 -cows was $1.7 \pm$ $0.6 \mathrm{~mol} \%$, and in that of ULP-cows $0.7 \pm 0.2 \mathrm{~mol} \%$. In the faeces of 0 and ULP-cows the contents of glutamic acid, methionine, isoleucine and tyrosine were greater than with NorP-cows, whereas the amounts of proline, glycine, histidine and arginine were smaller. In a feeding experiment with 
${ }^{15} \mathrm{NH}_{4} \mathrm{Cl}$ the slowest incorporation of ammonium nitrogen was into histidine, proline, arginine and glycine with both bacteria and protozoa in the rumen of the ULP-cows (SYväoja and Kreula 1979). The amino acid composition of NorP-cows' faeces was almost the same as that in the studies of TAmmingA (1975). Exceptions are found in the larger amounts of tyrosine, alanine and glutamic acid and the smaller amounts of histidine and methionine in the present studies. TAMminga determined only the amino acids present in protein.

Compared with the hydrolyzate of the insoluble fraction of the rumen, the proportion of $\alpha, \varepsilon$-diaminopimelic acid, alanine, glycine and valine of the total identified amino acids in the hydrolyzate of the faeces of 0 -cows was high and that of arginine low. The proportion of glucosamine of the total amount of amino acids was $2.9 \pm 1.9 \%$ in the faeces of 0 -cows, $2.2 \pm 0.3 \%$ in that of ULP-cows and $1.3 \pm 0.2 \%$ in the faeces of NorP-cows, $0.1 \%$ in rumen hydrolyzate from 0-cows (MÄKINEN 1972) and $0.2 \%$ in that from ULP- and NorP-cows. The fact that the amounts of $\alpha, \varepsilon$-diaminopimelic acid and glucosamine in the faeces are greater than in the rumen seems to show that there are large amounts of bacterial cell wall in the faeces. According to HoogenRAAD at al. (1970), glutamic acid, alanine and diaminopimelic acid along with muramic acid and glucosamine make up the peptidoglycan portion of the bacterial cell (B. subtilis). In successive hydrolyses performed with papain and pepsin it was possible to liberate 37 and $30 \%$ respectively of the amino acids of the insoluble fraction of the faeces of ULP-cows. HoogenRAAD and HIRD (1970) were able to release $45 \%$ of the total amount of amino acids of the bacterial cell walls with pepsin, and $30 \%$ with chymotrypsin. According to an unpublished study of our laboratory there were $1.6-4.0 \times 10^{8}$ living anaerobic bacteria and $3.4-7.9 \times 10^{6}$ aerobic bacteria per $g$ fresh faeces with 0 -cows; the corresponding figures with ULP-cows were $3.0 \times 10^{6}-3.9 \times 10^{9}$ and $4.2 \times 10^{6}-2.6 \times 10^{8}$.

It is clear that on 0 -feed in which urea was the sole source of nitrogen the faeces contained both microbial and endogenic nitrogen, but on the two other feeds the faeces probably contained also indigestible feed nitrogen. MAsoN (1969) reported that the indigestible feed nitrogen was $3.2-28.3 \%$ of the total nitrogen of the faeces, with sheep. As for the present studies, it seems that much of the feed nitrogen was converted to microbial nitrogen. It is likely that on all but nitrogen-free rations a variable but important part of the bacterial nitrogen in the faeces is derived directly from the feed (MAson 1969, 1971).

The peptide fraction also contained $\alpha, \varepsilon$-diaminopimelic acid and glucosamine, and with some cows $\alpha, \varepsilon$-diaminopimelic acid was present even in the free amino acid fraction. MASON and co-workers (MASON and WHITE 1971, MASON and Milne 1971) found evidence that the sheep is unable to digest diaminopimelic acid-containing mucopeptide with its own enzyme systems. A decreased amount of diaminopimelic acid passing through the rectum indicated partial removal or destruction of this amino acid in the hindgut, probably as a result of microbial activity. These authors point out that though much of the watersoluble nitrogen of faeces is of bacterial origin, a large proportion must be degraded pigments, enzymes and other secretions. 
BEET, A. E. 1955. Potassium permanganate in the Kjeldahl method for the determination of nitrogen in organic substances. Nature 175:513-514.

Ettala, T. \& Kreula, M. 1976. Milk production on low-protein, urea-rich feed. Acta Agric. Scand. 26: 33-39.

HoogenraAd, N. J. \& Hird, F. J. R. 1970. Factors concerned in the lysis of bacteria in the alimentary tract of sheep. J. Gen. Microbio.. 62: 261-264.

- , Hird, F. J. R., White, R. G. \& Leng, R. A. 1970. Utilization of ${ }^{14}$ C-labelled Bacillus subtilis and Escherichia coli by sheep. Br. J. Nutr. 24:129-144.

Kreula, M. \& Ettala, T. 1977. Digestibility and nitrogen balance of the feed of dairy cows with urea as the sole or partial source of nitrogen. J. Scient. Agric. Soc. Finl. 49: 192198.

Mason, V. C. 1969. Some observations of the distribution and origin of nitrogen in sheep faeces. J. Agric. Sci., Camb. 73: 99-111.

- 1971. Some preliminary observations on the nature of factors influencing the excretion of non-dietary faecal nitrogen by ruminant arimals. J. Agric. Sci., Camb. 76:157166.

- \& White, F. 1971. The digestion of bacterial mucopeptide constituents in the sheep. 1. The metabolism of 2,6-diaminopimelic acid. J. Agric. Sci., Camb. 77:91-98.

— \& Milne, G. 1971. 2. The digestion of muramic acid. J. Agric. Sci., Camb. 77: 99-101.

MÄKINEN, S. 1972. Aspects of the nitrogen metabolism and nutritional status of urea-fed dairy cattle. Ann. Acad. Sci. Fenn. A II Chem. 165: 1-67.

Piez, K. A. \& Morris, L. 1960. A modified procedue for the automatic analysis of amino acids. Anal. Biochem. 1:187-201.

Syväoja, E.-L. \& KreUlA, M. 1979. Incorporation of ${ }^{15} \mathrm{~N}$ and ${ }^{14} \mathrm{C}$ into amino acids of bacterial and protozoal protein in the rumen of the cow on urea-rich feed. J. Scient. Agric. Soc. Finl. 51: $497-505$.

TAMminga, S. 1975. Observation on protein digestion in the digestive tract of dairy cows. 1. Distribution of amino acids in rumen microbes and digesta. Z. Tierphysiol. Tierernähr. Futtermittelk. 35: 337-346.

Virtanen, A. I. 1963. Produktion der Kuhmilch ohne Protein mit Harnstoff und Ammoniumsalzen als Stickstoffquelle und gereinigten Kohlenhydraten als Energiequelle. Biochem, Z. 338 : 443-453.

- 1966. Milk production of cows on protein-free feed. Science 153:1603-1614.

- 1967. Milk production on a protein-free and proteinpoor feed. Neth. Milk Dairy J. 21: $223-244$.

Ms received July 4, 1979 


\title{
Lannan typpiyhdisteistä lypsylehmillä, joilla urea on ollut ainoana tai osittaisena typenlähteenä
}

\author{
Tertru Etrala ja Matri Kreula \\ Biokemiallinen Tutkimuslaitos, Kalevankatu 56 b, 00180 Helsinki 18
}

Lypsylehmien lannan typpiyhdisteitä on tutkittu puhdistetulla proteiinittomalla ruokinnalla, jossa ainoana typenlähteenä on ollut urea ja vähäisessä määrässä ammoniumsuolat (0-ruokinta), vähän proteiinia sisältävällä ruokinnalla, jossa puuttuva proteiini on korvattu urealla (ULPruokinta) ja tavanomaisella proteiinia sisältävällä ruokinnalla (NorP-ruokinta).

Lannan kokonaistyppipitoisuudet ovat olleet 0 -ruokinnalla $2,5 \pm 0.7 \%$, ULP-ruokinnalla $2.4 \pm 0.4$ ja NorP-ruokinnalla $2.3 \pm 0.6 \%$ kuiva-aineesta. Urea- ja ammoniumtypen osuus on vastaavasti ollut $3.2 \pm 2.4,4.5 \pm 2.4$ ja $3.7 \pm 1.8 \%$ kokonaistypestä, $70 \%$ :seen etanoliin liukenevan typen osuus $10.9 \pm 5.7,9.9 \pm 2.4$ ja $10.4 \pm 3.8 \%$ kokonaistypestä. Erot eivät ole olleet tilastollisesti merkitseviä. Vapaiden aminohappojen typen osuus on ollut 0 -ruokinnalla $4.1 \pm 2.9$, ULP-ruokinnalla $1.6 \pm 1.4(\mathrm{P}<0.05)$ ja NorP-ruokinnalla $3.2 \pm 2.9 \%$ kokonaistypestä.

$70 \%$ :seen etanoliin liukenematonta typpeä on ollut 0 -ruokinnalla $82.3 \pm 7.2$, ULP-ruokinnalla $85.4 \pm 5.0$ ja NorP-ruokinnalla $82.3 \pm 7.2 \%$ kokonaistypestä.

Liukenemattoman typen fraktiosta on happohydrolyysillä vapautunut aminohappotyppeä 0-ruokinnalla $62.8 \pm 8.5 \%$, ULP-ruokinnalla $61.6 \pm 10.7 \%$ ja NorP-ruokinnalla $59.0 \pm 13.9$ $\%$ kokonaistypestä. Vapautuneista aminohapoista on $\alpha, \varepsilon$-diaminopimeliinihapon osuus ollut vastaavasti $1.7 \pm 0.6,0.7 \pm 0.2(\mathrm{P}<0.05)$ ja $1.2 \pm 0.4$ mooliprosenttia.

Liukenevan typen fraktiosta on määritetty vapaat ja happohydrolyysillä vapautuneet speptidi»-fraktion aminohapot. 